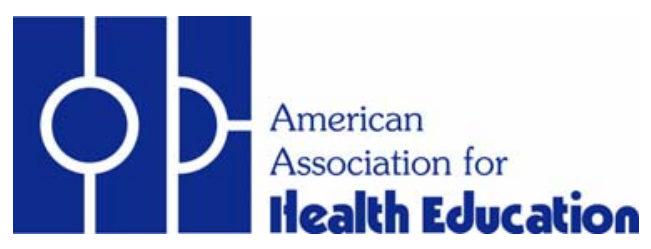

\title{
AAHE At-A-Glance
}

Volume 4 Issue 2, June 1, 2006

In this issue of AAHE AT-A-Glance, you will find updates on:

- 2006 AAHE \& NASPE Faculty Development Institute

Page

vii

- $\quad$ AAHE Mid-Year Meeting: Promoting Health Together

August 28 - 31, 2006, Nashville, TN

xi

- $\quad$ AAHE Committee Appointees: A Professional Service Opportunity

- National Health Education Week

xiv

Thank you for reading.

For more information, please go to the AAHE website --

http://www.aahperd.org/aahe

Susan Giarratano Russell, EdD, MSPH, CHES

AAHE Contributing Editor

Valencia, California

The American Association for Health Education serves health educators and other professionals who promote the health of all people. AAHE encourages, supports, and assists health professionals concerned with health promotion through education and other systematic strategies. 

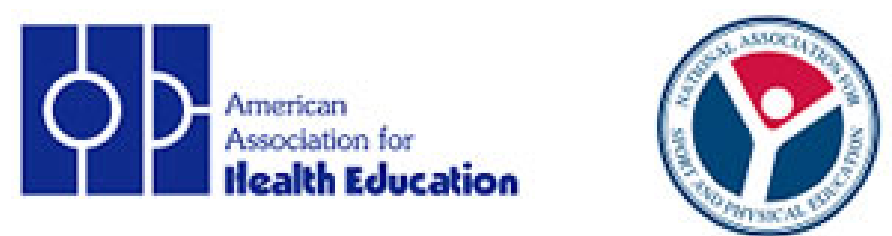

\section{AAHE \& NASPE Faculty Development Institute National Convention Center Lansdowne, Virginia September 28 - September 30, 2006}

The American Association for Health Education (AAHE), in collaboration with the National Association for Sport and Physical Education (NASPE), is hosting its 3 rd Annual Faculty Development Institute. The primary purpose of the Institute is to enhance the capacity of colleges and universities in the preparation of teacher candidates.

\section{Who Should Attend?}

- Health Education Faculty

- Physical Education Teacher Education Faculty

- SEA and LEA Health Education Coordinators

\section{Institute Highlights}

This institute will provide 7 workshops that will focus on faculty and staff development in the following areas:

- Creating Professional Development Opportunities for Implementation of the National Health Education Standards, PreK-12 Thursday, September 28, 2006, 8:00 am - 12:00 noon Workshop Fee \$75

The participants will be trained as trainers for delivering professional development to preK-12 classroom teachers, local education agency personnel, state education agency personnel and university professional preparation faculty. Participants will receive a book entitled National Health Education Standards: Achieving Excellence.

- Standards-based Health Education \& Performance Assessment Workshop Thursday, September 28, 2006, 1:00 pm - 5:00 pm Workshop Fee $\$ 75$

The workshop will provide health education teacher preparation faculty with the knowledge and skills needed to professionally prepare teachers to effectively use the National Health Education Standards and performance-based assessment to promote health literacy. Faculty are strongly urged to combine this with the Assessments and Scoring Rubrics Development Workshop. The participants will receive a manual on standards-based health education \& performance assessment entitled "Health Literacy: 
Teaching HIV Prevention through Standards-based Health Education \& Performance Assessment," and a CD-ROM which contains PowerPoint presentations, handouts, and overheads.

- $\quad$ Assessments and Scoring Rubrics Development Workshop

Friday, September 29, 2006, 9:00 am - 5:00 pm

Workshop Fee $\$ 100$

This workshop will assist faculty from both disciplines in constructing assessments and using scoring rubrics and other types of scoring guides for instruction and evaluation. The special focus for this workshop will be writing assessments and rubrics to meet requirements for NCATE program reports.

- Physical Best Health-Fitness Specialist Certification

Friday September 29, 2006, 8:00 am - 5:00 pm

Workshop Fee $\$ 150$

This workshop will provide comprehensive training in Physical Best, a practical and ready to use lifelong fitness education resource for educators, and an overview of FITNESSGRAM software. Participants will engage in hands on Physical Best activities that teach components and principles of health-related fitness education and with the FITNESSGRAM assessment protocols. All participants will receive the following Physical Best books: Physical Education for Lifelong Fitness: The Physical Best Teacher's Guide, Physical Best Activity Guide, FITNESSGRAM Test Administration Manual.

- AAHE/NCATE University Preparation Workshop Saturday, September 30, 2006, 8:00 am - 5:00 pm Workshop Fee $\$ 100$

This workshop will provide guidance to institutions of higher education in preparing a health education program report for AAHE/NCATE review. In addition, the workshop participants will receive training and handouts on the new web-based program report submission and review. Each institution will receive one copy of 2001 Guidelines for AAHE/NCATE Review of Initial Level Programs for Health Education Teacher Preparation, and CD-ROM containing the guidelines document.

- NASPE/NCATE PETE Program Report Preparation Workshop and Reviewer Training - Initial Standards Saturday, September 30, 2006, 8:00 am - 5:00 pm Workshop Fee \$100

This workshop will provide guidance to university physical education teacher preparation programs on preparing an electronic program report for NASPE/NCATE review. The workshop participants will receive training and handouts on the web-based program report submission process at the initial PETE standards level. Each participant will 
receive handouts and templates to clarify the program report preparation process. All participants will receive materials related to developing evidence, assessments, scoring guides, and collecting data for the electronic program report. This session is complemented by the information provided in the Friday Assessments and Scoring Rubrics Development Workshop. In addition, participants will be trained as electronic program report reviewers in the afternoon and receive in depth instruction related to review for program approval at the initial standards level.

- NASPE/NCATE PETE Program Report Preparation Workshop and Reviewer Training-Advanced Standards Saturday, September 30, 2006, 8:00 am - 5:00 pm Workshop Fee \$100

This workshop will provide guidance to university physical education Masters Teacher preparation programs on preparing an electronic program report for NASPE/NCATE review. The workshop participants will receive training and handouts on the web-based program report submission process at the advanced PETE standards level. Each participant will receive handouts and templates to clarify the program report preparation process. All participants will receive materials related to developing evidence, assessments, scoring guides, and collecting data for the electronic program report. This session is complemented by the information provided in the Friday Assessments and Scoring Rubrics Development Workshop. In addition, participants will be trained as electronic program report reviewers in the afternoon and receive in depth instruction related to review for program approval at the advanced standards level.

\section{More information:}

o Continuing education credit, including CHES credit, will be available.

o Each workshop is limited to 40 participants.

o Deadline for registration is September 15, 2006

o For more information, please call 1-800-213-7193, Amy Feinberg, ext. 437 and De Raynes, NASPE, ext. 414.

o For updated information, and registration go to www.aaheinfo.org, or go to the registration form on the next page.

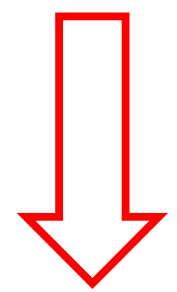




\section{Registration Form \\ 2006 AAHE \& NASPE Faculty Development Institute \\ National Conference Center - Lansdowne, Virginia \\ September 28 - 30, 2006}

Name

Title

Organization

Address

City State Zip

Phone Fax

Email

Lodging Fee (Check all that apply):

Wednesday $\rightarrow \$ 170.50$

․ Thursday $\rightarrow \$ 170.50$

口 Friday $\rightarrow \$ 170.50$

口 Saturday $\rightarrow \$ 170.50$

口 I do not need lodging

Daily Attendee Fee - No Lodging (Check all that apply)

a Thursday $\rightarrow \$ 57.75$

a Friday $\rightarrow \$ 57.75$

a Saturday $\rightarrow \$ 57.75$

a I am lodging

I plan to attend (Check all that apply)

a Implementing Pre K-12 National Health Standards - \$75

口 Standards \& Performance Assessment Workshop - \$75

- Assessment and Scoring Rubrics Development Workshop - \$100

口 AAHE/NCATE University Preparation Workshop - \$100

a NASPE/NCATE PETE Program Report Preparation Workshop and Reviewer Training - Initial Standards $\$ 100$

- NASPE/NCATE PETE Program Report Preparation Workshop and Reviewer Training - Advanced Standards - $\$ 100$

a Physical Best- Fitness Specialist Certification - \$150

Total Remittance

\section{Method of Payment}

口 Check made payable to AAHPERD $\rightarrow$ enclosed with registration form

a Purchase Order - $\rightarrow$ enclosed with registration form

व VISA

a MasterCard

口 American Express

You may register online at http://www.aahperd.org/aahperd/template.cfm?template=facdev/main.html Registration Deadline: September 15, 2006 


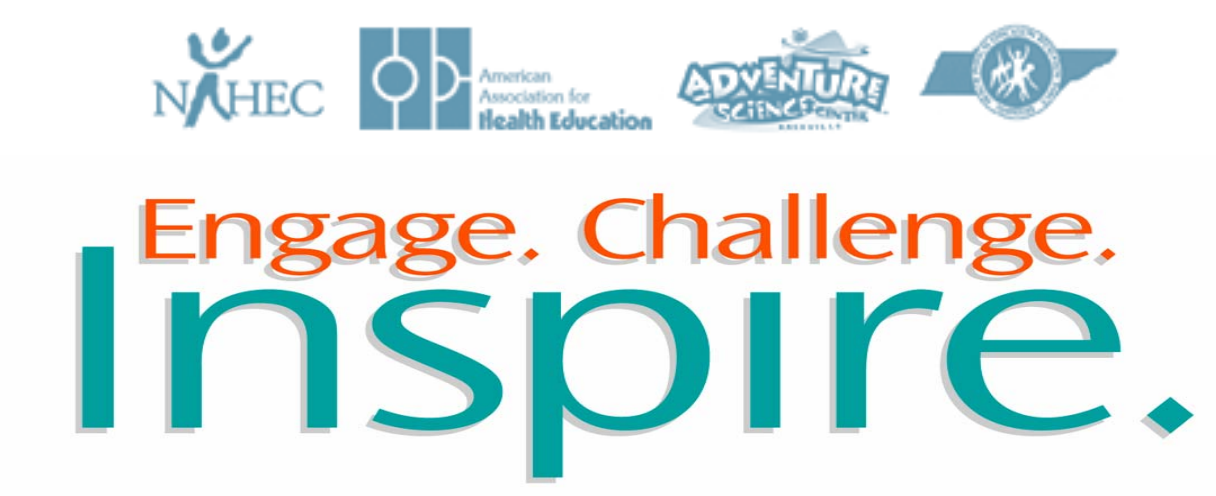

TURNING SERIOUS HEALTH EDUCATION INTO CHILD'S PLAY

\title{
National Association of Health Education Centers \\ $18^{\text {th }}$ Annual Conference
}

\section{American Association for Health Education \\ Mid-year Meeting}

\section{Promoting Health Together}

\author{
August 28 - 31, 2006 \\ Nashville, Tennessee \\ Hosted by Adventure Science Center \\ and \\ Tennessee Association for Health, Physical Education, Recreation, and Dance
}

\section{Conference Theme}

The conference theme is Engage. Challenge. Inspire. Turning Serious Health Education Into Child's Play, with special attention on the need to address overweight and obesity.

\section{Conference Features}

o Programs for health educators, administrators, marketing and fund raising staff

o Professional development opportunities that increase knowledge and improve skills

o CHES credits available

o Exhibitors providing products and services to health education centers

\section{Conference Sessions}

Sessions will follow three tracks: Administrative \& Operations (ADM), Marketing \& Resource Development (DEV), and Teaching \& Learning Strategies (EDU). See Agenda @ http://www.nahec.org/htmdocs/calendar/nahec_conference/2006/agenda.html 


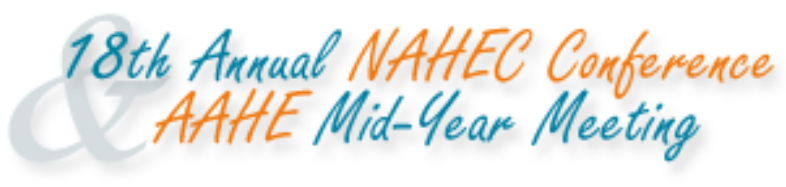

\section{Conference Registration and Fees}

\section{Registration fees:}

Includes professional and business meetings, exhibits, and awards luncheon. Professional sessions include keynote presentations, breakout sessions, teaching technique sessions, and poster sessions. Continuing education credits for professionals, specials events and preconference workshops require additional fees.

\begin{tabular}{llllc} 
& \multicolumn{1}{l}{ Early (by 6/30) } & Advance (by 8/18) & On-Site & Daily Attendees \\
\cline { 2 - 5 } Professional Members & $\$ 160$ & $\$ 185$ & $\$ 215$ & $\$ 75$ \\
Non-member & $\$ 240$ & $\$ 275$ & $\$ 325$ & $\$ 115$ \\
Students & $\$ 50$ & $\$ 50$ & $\$ 50$ & $\$ 25$
\end{tabular}

*Students must be registered at an accredited institution of higher education

Hotel Room Rate: $\quad$ TBD

CHES credits available (12-16 Category I): Flat fee of \$30

Register for the conference:

http://www.nahec.org/htmdocs/calendar/nahec_conference/2006/registration.html

For more information:

Call (414) 390-2187 or send an e-mail to kschlapman@nahec.org

\begin{abstract}
About the Associations
National Association of Health Education Centers (NAHEC):

is the national association and network of nonprofit, interactive health education centers (HECs) and of other organizations that support children's health education and provide products and services for HECs. HECs offer a variety of programs to school field trips in theater-style classrooms and/or in "outreach" to schools utilizing life-sized exhibits, advanced technology, multimedia, hands-on activities, and interactive programs not generally found in conventional classrooms. They may be independent, community based organizations or affiliated with other public institutions (hospitals, museums, schools, science centers, or universities). For more information about NAHEC, check out www.nahec.org
\end{abstract}

American Association for Health Education (AAHE):

advances the profession by serving health educators and other professionals who strive to promote the health of all people. The leaders and members realize this mission through a comprehensive approach that encourages, supports, and assists health professionals concerned with health promotion through education and other systematic strategies. AAHE serves professionals in a variety of settings: healthcare, community/public agencies, businesses, schools (Pre-K-12), and institutions of higher learning. For more information about AAHE, check out www.aaheinfo.org 


\section{AAHE COMMITTEE APPOINTEES: A PROFESSIONAL SERVICE OPPORTUNITY}

AAHE members are sought to serve on the AAHE standing committees each year. AAHE members can either self-nominate or nominate someone they believe would be good for a committee. All committees meet during the national convention and usually have e-mail communications, telephone conferences and/or committee work assignments throughout the year. AAHE committee involvement is an excellent way to get involved, network with health education professionals, and advance the profession. Whether you have "matured" in the profession or are a brand new health educator, we need your participation.

AAHE has the following standing committees:

Advocacy Committee - advocate on behalf of the AAHE membership in predetermined areas of interest; to promote and enhance health education related legislation; to organize grass roots responses to health education related legislation; to raise public awareness of health related topics and issues Awards Committee - review \& final selection for AAHE Scholar, Professional Service \& Distinguished Service Awards \& AAHE Health Education Professional of the Year Awards Board of Associate Editors - make editorial policy for the American Journal of Health Education [AJHE] and the International Electronic Journal of Health Education [IEJHE]

Ethics Committee - develop procedures to educate AAHE membership regarding ethical practices, apply the code of ethics, recommend changes in the code as deemed necessary and represent AAHE on ethic issues

History \& Philosophy Committee - develop \& promote the historical foundation; serve as a resource regarding collection \& dissemination of historical information \& documents; facilitate basis of health education; promote historical \& philosophical research; promote the inclusion of health education history \& philosophy in professional preparation

Membership Committee - develop campaigns to recruit new \& members \& strategies to increase member retention \& satisfaction

Multicultural Involvement Committee - fulfill the AAHE goal of cultural pluralism in membership, leadership and throughout the profession

Nominations Committee - review \& select candidates for AAHE Officers and Board

NCATE Review Committee - conduct surveillance of guidelines, review folios; must serve as an

AAHE/NCATE reviewer prior to serving on the Committee

Professional Development Committee - oversee continuing education \& professional development activities

Research Coordinating Board - oversee \& plan research activities

Scholarship Committee - evaluate\& select the recipients of the AAHE Scholarships

Student Involvement Committee - work with students: in membership recruitment/retention, leadership roles in AAHE/AAHPERD, involvement in programming, recognition activities, and liaison with Eta Sigma Gamma

*SOPHE/AAHE Baccalaureate Program Approval Committee (SABPAC) conduct surveillance of guidelines, and review of programs

DO YOU WANT TO BE INVOLVED IN AAHE? SEND YOUR CONTACT INFORMATION BY AUGUST 15, 2006 TO:

Linda M. Moore

AAHE

E-mail: $\underline{\text { lmoore@aahperd.org }}$

PLEASE NOTE THE COMMITTEES THAT PARTICULARLY INTEREST YOU! 


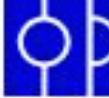

AMERICAN ASSOCIATION FOR HEALTH EDUCATION

\section{NATIONAL HEALTH EDUCATION WEEK}

The American Association for Health Education (AAHE) invites you to celebrate National Health Education Week, which is the third week of October.

This year it is October 16-20 2006. We encourage you to take this opportunity to Advocate for Health Education and Health Promotion!

A - Advocate for health literacy through health education

D - Develop celebration activities for your school/organization

V - Voice your support for health education and promotion

O - Organize others in celebration

C - Collaborate with other health care and educational professionals

A - Advance health education throughout the year

T - Treat everyone to an exciting health education/promotion experience

E - Educate the community about the value of health education 